\title{
Depression, Anxiety, and Lifestyle Among Essential Workers: A Web Survey From Brazil and Spain During the COVID-19 Pandemic
}

Raquel Brandini De Boni ${ }^{1}$, MD, MSc, PhD; Vicent Balanzá-Martínez ${ }^{2}$, MD, PhD; Jurema Correa Mota ${ }^{1}$, PhD; Taiane De Azevedo Cardoso ${ }^{3}, \mathrm{MSc}, \mathrm{PhD}$; Pedro Ballester ${ }^{4}, \mathrm{MSc}$; Beatriz Atienza-Carbonell ${ }^{5}$, MD; Francisco I Bastos ${ }^{1}$, MD, MSc, PhD; Flavio Kapczinski ${ }^{3,6,7}$, MD, MSc, PhD, FRCPC

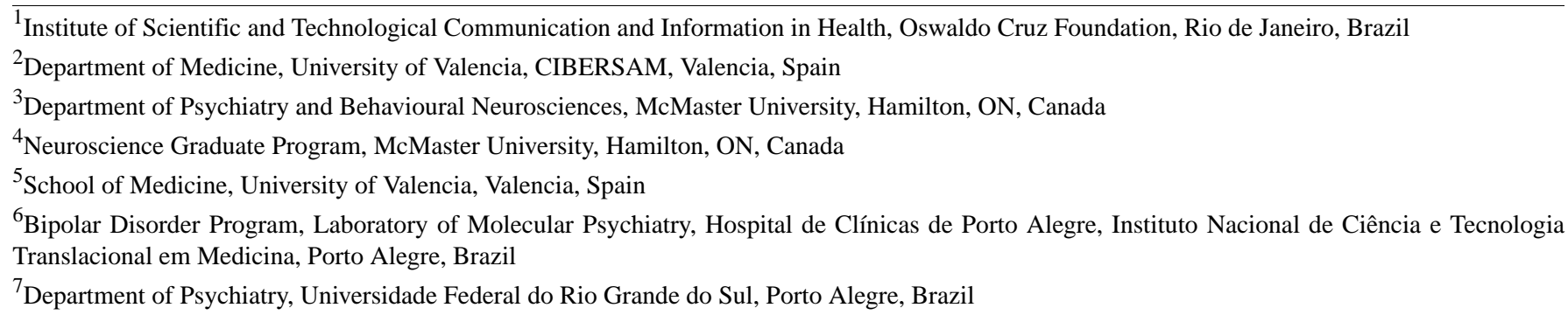

\section{Corresponding Author:}

Raquel Brandini De Boni, MD, MSc, PhD

Institute of Scientific and Technological Communication and Information in Health

Oswaldo Cruz Foundation

Av Brasil 4365 Pavilhao Haity Moussatche, Room 229

Rio de Janeiro, 21040-360

Brazil

Phone: 552138653231

Email: raqueldeboni@gmail.com

\section{Abstract}

Background: Essential workers have been shown to present a higher prevalence of positive screenings for anxiety and depression during the COVID-19 pandemic. Individuals from countries with socioeconomic inequalities may be at increased risk for mental health disorders.

Objective: We aimed to assess the prevalence and predictors of depression, anxiety, and their comorbidity among essential workers in Brazil and Spain during the COVID-19 pandemic.

Methods: A web survey was conducted between April and May 2020 in both countries. The main outcome was a positive screening for depression only, anxiety only, or both. Lifestyle was measured using a lifestyle multidimensional scale adapted for the COVID-19 pandemic (Short Multidimensional Inventory Lifestyle Evaluation-Confinement). A multinomial logistic regression model was performed to evaluate the factors associated with depression, anxiety, and the presence of both conditions.

Results: From the 22,786 individuals included in the web survey, 3745 self-reported to be essential workers. Overall, $8.3 \%$ $(\mathrm{n}=311), 11.6 \%(\mathrm{n}=434)$, and $27.4 \%(\mathrm{n}=1027)$ presented positive screenings for depression, anxiety, and both, respectively. After adjusting for confounding factors, the multinomial model showed that an unhealthy lifestyle increased the likelihood of depression (adjusted odds ratio [AOR] 4.00, 95\% CI 2.72-5.87), anxiety (AOR 2.39, 95\% CI 1.80-3.20), and both anxiety and depression (AOR 8.30, 95\% CI 5.90-11.7). Living in Brazil was associated with increased odds of depression (AOR 2.89, 95\% CI 2.07-4.06), anxiety (AOR 2.81, 95\%CI 2.11-3.74), and both conditions (AOR 5.99, 95\% CI 4.53-7.91).

Conclusions: Interventions addressing lifestyle may be useful in dealing with symptoms of common mental disorders during the strain imposed among essential workers by the COVID-19 pandemic. Essential workers who live in middle-income countries with higher rates of inequality may face additional challenges. Ensuring equitable treatment and support may be an important challenge ahead, considering the possible syndemic effect of the social determinants of health.

(J Med Internet Res 2020;22(10):e22835) doi: 10.2196/22835 


\section{KEYWORDS}

COVID-19; depression; anxiety; lifestyle; Brazil; Spain

\section{Introduction}

The prevalence of COVID-19 continues to increase in Brazil [1], and mental health is recognized as an important challenge ahead worldwide [2-4]. Several studies have used web surveys to screen for common mental health disorders (mainly depressive and anxiety disorders) among the general population [5-8]. Some of these studies, but not all [9,10], have shown that essential workers, such as health care workers (HCWs), had an increased likelihood of anxiety and depression compared to other workers [11,12]. Essential workers may have increased workload and working hours during the pandemic [13], struggle with the lack of adequate personal protective equipment [14], and may be isolated from friends and families [15]. Burnout symptoms [16], emotional exhaustion [17], and fear of transmitting the virus [18] are commonly reported.

The first study investigating mental health problems among essential workers during the COVID-19 pandemic was conducted in China and found the prevalence of anxiety and depressive symptoms to be at $20.1 \%$ and $12.7 \%$, respectively [19]. In two subsequent systematic reviews, HCWs presented increased depression/depressive symptoms, anxiety, psychological distress, and poor sleep quality [20,21]. The first meta-analysis evaluating the prevalence of mental health problems among HCWs (up to April 13, 2020) found 13 studies ( $\mathrm{N}=33,062$ participants), of which 12 were conducted in China. The pooled prevalence of a positive screening for anxiety was $23.2 \%$ (95\% CI 17.8-29.1) while depression was estimated at $22.8 \%$ (95\% CI 15.1-31.5) [22]. Evidence from outside of China is still scarce [23-30], and it is difficult to estimate the overall prevalence of common mental health disorders due to methodological issues, heterogeneity in study populations and sizes, and differences in criteria used to define a case (eg, different instruments and cut-offs). For instance, the prevalence of depression was as low as $10 \%$ among HCWs in Singapore and India [23] to as high as $64.7 \%$ among physicians in Turkey [31].

Four major groups of variables have been associated with an increased likelihood of having a positive screening for anxiety and/or depression among essential workers during the COVID-19 pandemic: demographic, professional/financial worries, COVID-19 exposure factors, and personal health factors. In terms of demographics, being female and younger were more frequently associated with depression $[31,32]$ while a higher education level and residing in areas or provinces with a greater number of cases have been associated with anxiety $[19,33,34]$. Worrying about adequate training, knowledge, preparedness, and finances, as well as self-efficacy and career phase, were some of the professional/financial variables analyzed under this domain [34]. COVID-19 exposure variables included being a frontline worker [31,33,34]; fear, suspicion, or diagnosis of COVID-19 for oneself and/or their significant other [19,32,33,35]; and having a deceased colleague [32]. Finally, regarding personal health factors, included variables were perceived stress [19], poor sleep $[19,26]$, presence of a previous medical or psychiatric disorder [31,35], and a history of alcohol consumption [35]. Of note, good social support was frequently associated with a decreased likelihood of anxiety and depression among essential workers $[19,36]$.

The fast growing field of lifestyle psychiatry [37] has been providing evidence on how health behaviors (eg, diet, physical activity, smoking, and sleep) relate to the prevalence, incidence, and adverse outcomes of mental health disorders [38-40]. For instance, consistent results point to the beneficial effects of physical activity in preventing the onset of depression as well as improving its symptoms [40]. As many people around the world are under confinement due to the COVID-19 pandemic, changes in lifestyle behaviors have attracted more research interest [41]. Behaviors, such as sleep quality [36,42], were assessed among HCWs instead of using a comprehensive, multidimensional approach to lifestyle. Multidimensional evaluations of lifestyle are still scarce [41], although it is possible that different health behaviors share a common pathway to improve mental health, such as anti-inflammatory effects $[43,44])$.

Considering the social determinants of health $[45,46]$, it is possible that countries presenting poor social and health indicators may present a higher prevalence of unhealthy outcomes, which could include both COVID-19-related and mental health problems. Herein, we have included two countries with different social and health indicators, and at different stages of the COVID-19 pandemic, as summarized in Figure 1 [47-50]. Brazil has roughly 4.5 times the population of Spain, but 0.4 times the GDP (gross domestic product) and 0.4 times the expenditure on health. In addition, Brazil is considered one of the countries with the greatest inequalities in income/wealth globally, with a Gini index of 53.9. The first COVID-19 case was diagnosed on January 31, 2020, in Spain and on February 26, 2020, in Brazil, respectively. On May 2, 2020 (the midpoint of our data collection period), there were almost 25,000 deaths in Spain and 6000 deaths in Brazil. At that time, Spain was under a strict lockdown policy while the lockdown in Brazil was implemented partially and in select cities and counties.

So far, we are unaware of studies that have investigated mental health problems among essential workers from two countries presenting such different social and epidemic profiles. Thus, our major aim is to describe the prevalence of depression, anxiety, and the comorbidity of both, as well as their associated factors, among self-reported essential workers during the COVID-19 pandemic in Brazil and Spain. 
Figure 1. Select social and health indicators (2017) and the COVID-19 situation (as of May 2, 2020) for Brazil and Spain. GDP: gross domestic product. Data sources: Institute from Health Metrics and Evaluation [47], *World Health Organization [48,49], **World Bank 2017-2018 [50].
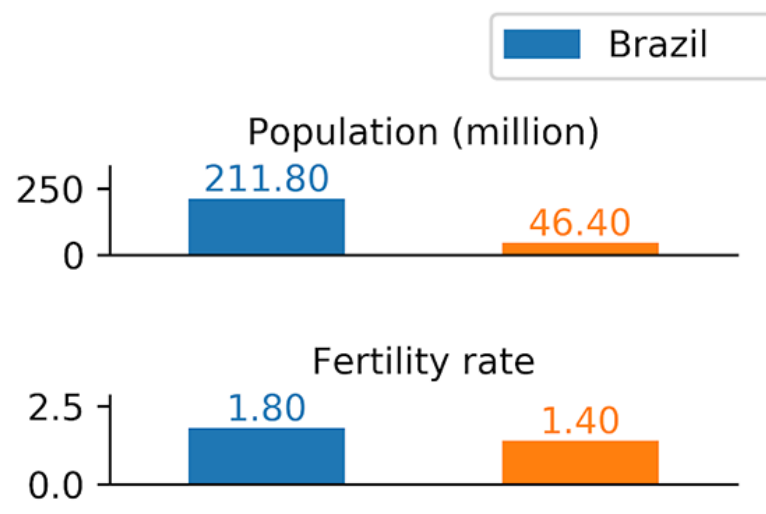

Life expectancy (years)

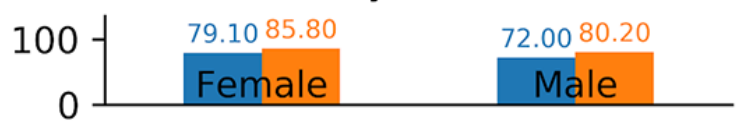

Expenditure on health per person (U\$)

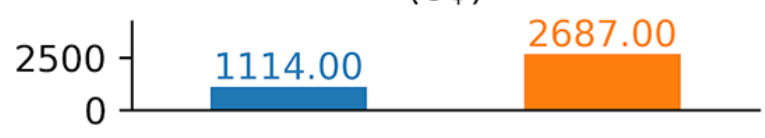

COVID-19 confirmed cases*

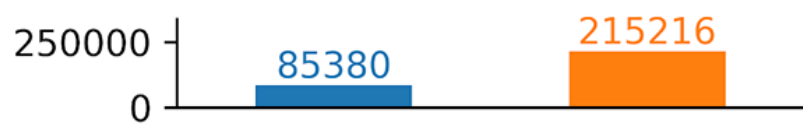

\section{Methods}

\section{Study Design}

A web survey was conducted from April 15 to May 15, 2020, in Spain and April 20 to May 20, 2020, in Brazil. The online questionnaire was created using SurveyGizmo and included questions about demographics, COVID-19 experience, lifestyle behaviors, self-rated health, and previous diagnosed conditions. The questionnaire comprised 101 questions, and skips, when appropriate, were implemented to decrease the time of completion (Multimedia Appendix 1). The usability and technical functionality were tested before launching the survey in both countries. In addition, participants could read information regarding ways to maintain a healthy lifestyle during the pandemic while they were answering the questionnaire, and were provided with additional websites and telephone numbers to find reliable information regarding COVID-19. This information was compiled from the COVID-19-related

\section{Spain}
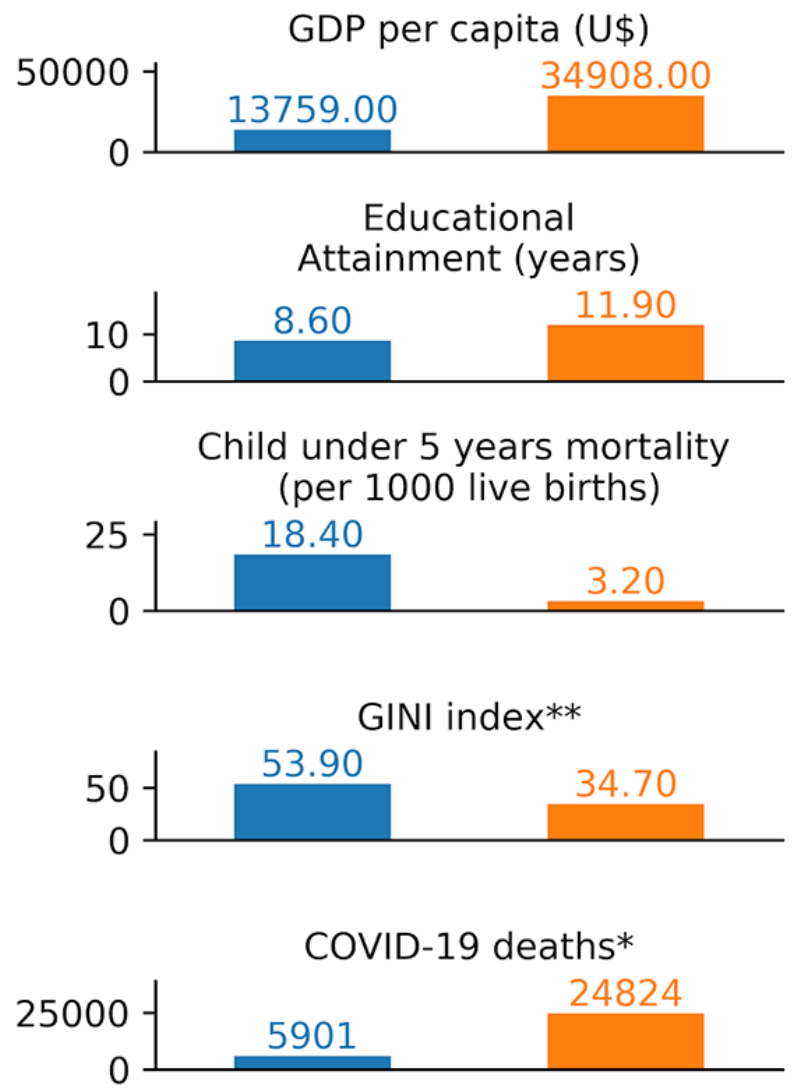

webpages of the Centers for Disease Control and Prevention, the National Institute of Health (United States), the Oswaldo Cruz Foundation, the Brazilian Ministry of Health, and the Spanish Ministry of Health.

\section{Study Population}

The study population included adults from both sexes living in Spain or in Brazil, who had access to the internet, and agreed to participate in the study after reading the informed consent form. Herein, we selected individuals who reported to be essential workers. Essential workers were considered all participants who answered "yes" to the following question: "Are you currently working as a health care worker or as a professional of other essential services (transportation, food, cleaning)?" To avoid duplicated responses, individuals who reported having previously completed the questionnaire were excluded (Figure 2) as no identification data (nor IP [Internet Protocol] address) were collected. 
Figure 2. Inclusion flowchart.
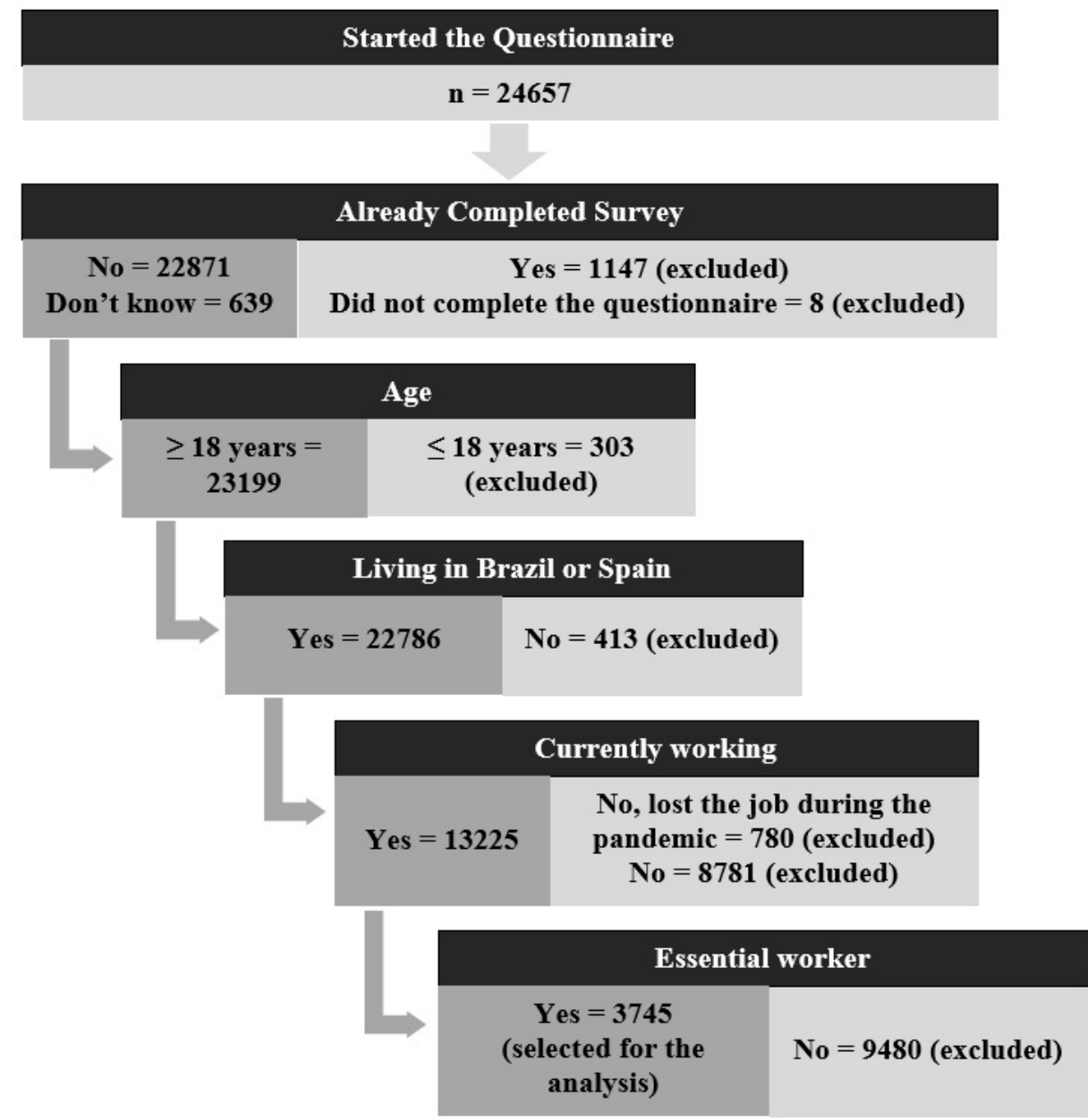

\section{Sample and Recruitment}

A convenience sample of participants was recruited via social networks (Facebook, WhatsApp, and Twitter) using a snowball technique and sponsored social network advertisements. A Facebook page for each country (Figure 3) was created and boosted using the following words: "healthy lifestyles," "sad," "happiness," "fear," "emotion," "stress," "well-being," "self-esteem," "quality of life," “motivation," "mind," "boredom," "panic," "interpersonal relationship," "life," "emotional intelligence," "physical fitness," and "physical exercise." According to Facebook, the page would reach 87 million people in Brazil and 290,000 individuals in Spain. Fundamental parameters were unknown when the sample size was defined, such as the possible participation of superrecruiters [51] with the potential to skew the sampling process, or whether or not there would be structural bottlenecks. Therefore, the sample size was not defined a priori; instead, a 30-day period of data collection was specified. 
Figure 3. Facebook pages created to disseminate the project and healthy lifestyle behaviors during the COVID-19 pandemic in Brazil and Spain.

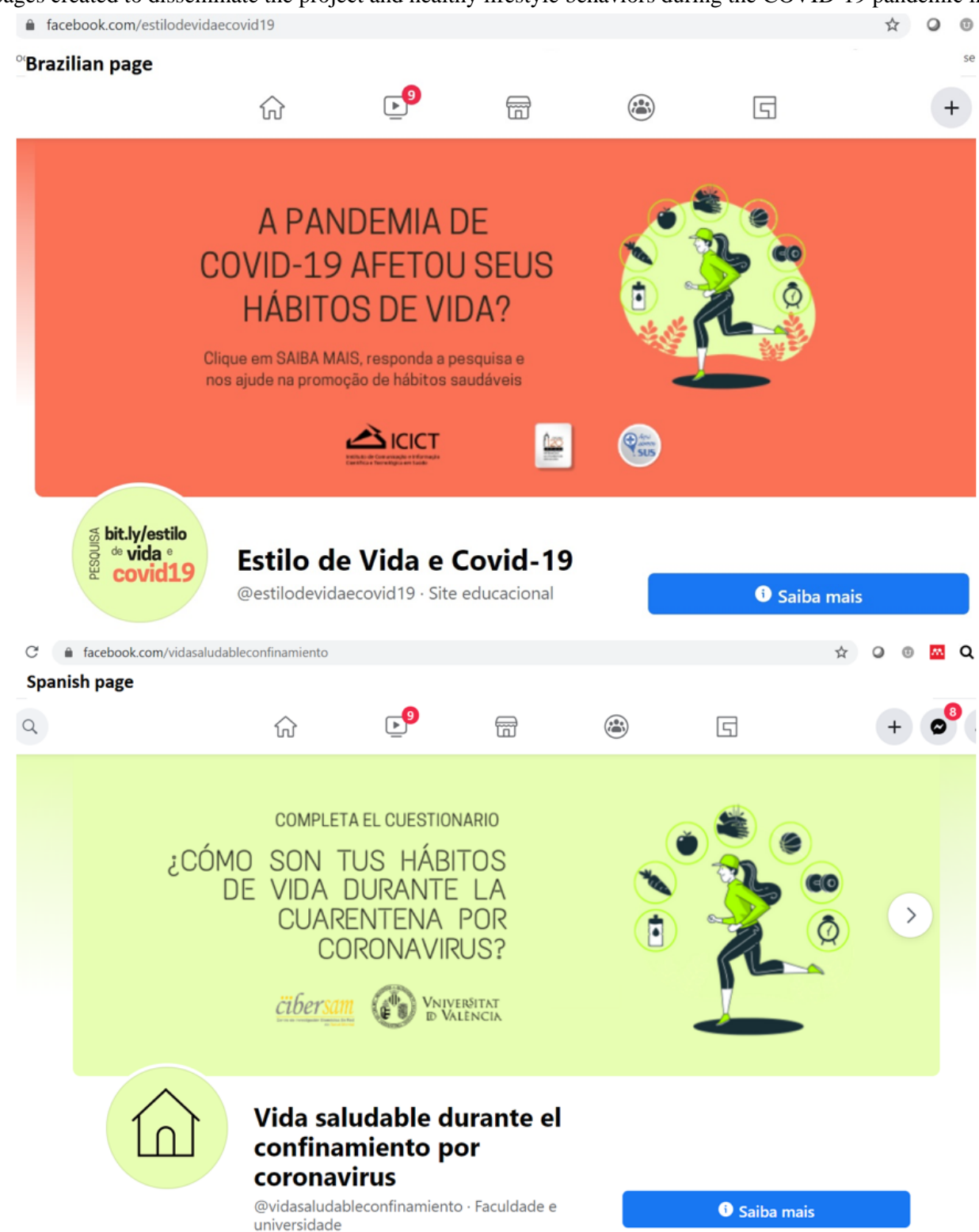

\section{Response Rates}

Response rates were not estimated in the study since the study denominator is unknown (ie, we were unable to estimate how many individuals had send the survey link via different-and probably overlapping-social networks).

\section{Variables and Measurements}

\section{Study Outcome (Dependent Variable)}

The main outcome is a positive screening for depression and/or anxiety. Depression was screened using the Patient Health Questionnaire-2 (PHQ-2 [52-55]; cut-off $\geq 3$ ), and anxiety was screened using the Generalized Anxiety Disorder 7-item scale (GAD-7 [56]; cut-off $\geq 10$ ). Subsequently, two dichotomous variables were created: "Positive Depression" and "Positive Anxiety." The outcome was a composite variable created using the aforementioned variables with the following categories: negative screening for both depression and anxiety, positive screening for depression only, positive screening for anxiety only, and positive screening for both depression and anxiety.

\section{Independent Variables}

Demographic information included sex, age, educational level (aggregated as primary/secondary education, a professional degree, a university degree, or a master's/PhD degree), number of people living in the household, frontline worker (yes/no), and country of residence (Brazil/Spain). Social distancing/self-isolation was considered as a dichotomous variable (yes/no).

Questions related to COVID-19 were as follows: "Have you been diagnosed with COVID-19?"; "Have you been admitted to a hospital or hospitalized due to COVID-19?"; and "Have you lost a significant other?" Possible answers were yes or no.

Lifestyle habits were assessed using the Short Multidimensional Inventory Lifestyle Evaluation-Confinement (SMILE-C) [41]. This scale was developed specifically to allow a multidimensional measure of lifestyle during the COVID-19 
pandemic. It comprises 27 items made up of 7 domains (diet and nutrition, substance abuse, physical activity, stress management, restorative sleep, social support, and environmental exposures), with response options measured using a 4-point Likert scale. The SMILE-C has an overall Cronbach $\alpha=0.75$ and Kaiser-Meyer-Olkin Measure $=0.77$. The higher the score, the healthier the lifestyle pattern. In this study, the SMILE-C total score was dichotomized at the 75 th percentile (up to $85 \%$ ).

Self-rated health was measured using the question "How would you rate your health in general?" with possible answer choices of "very bad," "bad," "neither good nor bad," "good," and "very good" [57]. Response options were aggregated into very good/good and neither good nor bad/bad/very bad.

Previously diagnosed conditions were investigated using the question "In the last 12 months, have you been diagnosed by a medical doctor or health professional, or received treatment for any of the following conditions?" Conditions included diabetes, heart disease, hypertension, stroke, anemia, asthma, depression, anxiety, bipolar disorder, schizophrenia, anorexia/bulimia, HIV/AIDS, cancer, tuberculosis, cirrhosis, and renal disease [58]. The conditions were then aggregated as chronic diseases, mental health disorders, and infectious diseases.

Screening for alcohol abuse was performed using the Alcohol Use Disorder Identification Test (AUDIT-C; cut-off $\geq 3$ [59]).

Changes in the SMILE-C domains during the pandemic were evaluated using questions like "Did you change your nutritional habits and diet during the COVID-19 pandemic?" Response options were measured using a 4-point Likert scale (completely, moderately, mildly, not at all) and aggregated into completely/moderately and mildly/not at all.

\section{Statistical Analysis}

Nonresponse treatment is described in Multimedia Appendix 2. Independent variables were described by outcome and proportions compared using chi-squared tests. Taking into consideration the complex, multiple associations of the different covariates with the outcomes under analysis (screening for depression and anxiety), preliminary analyses using Least Absolute Shrinkage and Selection Operator (LASSO [60, 61]), a simple machine learning procedure, were employed. LASSO is a penalized regression analysis method that helps to optimize variable selection and regularization in order to enhance the accuracy of the model to be implemented. The subset of factors (variables) that did not contribute to the hypothetical model under assessment yield zero coefficients [62]. Such variables were excluded from subsequent multivariable analyses (Multimedia Appendix 2).

The second procedure to optimize variable selection was based on the simulation of different modeling strategies with the subsequent choice of the best subset of variables to be included in a parsimonious model based on the best $\mathrm{R}^{2}$ coefficient [63, 64]. The glmnet library and the regsubsets function from $R$ 4.0.2 (The R Foundation) were used.

Using this subset of variables, a multinomial logistic regression was fitted, taking as the reference category "negative screening for both depression and anxiety." Analyses used the backward strategy, with the progressive elimination of variables based on the results of the Wald test and maximum likelihood estimation of fitness, considering a significance level of $5.0 \%$. The model fitness was evaluated using different diagnostic tools, such as the Hosmer-Lemeshow statistics, the Pearson chi-squared test, as well as the deviance information criterion. Additionally, an analysis of residuals was performed (Multimedia Appendix 2). The model yielded adjusted odds ratios (AORs) with their respective $95 \%$ CIs.

\section{Ethical Aspects}

The study was approved by the Ethics Committee at the Hospital Universitari i Politècnic La Fe in Valencia, Spain, and by the Comissão Nacional de Ética em Pesquisa (CONEP, Brazil 3.968.686). The survey was anonymous (no identifying data like name, zip code, or IP address were collected), and participants read the consent form and confirmed their interest in participating before starting the questionnaire. As mentioned before, as a direct benefit, participants were provided with tips on healthy lifestyles and reliable websites and telephone numbers for additional information regarding COVID-19.

\section{Results}

Overall, 24,657 questionnaires were initiated, and 22,786 were eligible for the main study. Of those, 3745 reported to be working as an essential worker during the COVID-19 pandemic and comprised the study sample (Figure 2). In total, 2842 participants were from Brazil and 903 from Spain. Most were female (Brazil: $\mathrm{n}=2052,72.2 \%$; Spain: $\mathrm{n}=640,70.9 \% ; P=.44$ ), with a median age of 39 (IQR 32-51) years for Brazil versus 43 (IQR 32-52) years for Spain $(P=.07)$. Half of the sample $(n=457$, $50.6 \%)$ reported being a frontline personnel in Spain compared to $28.9 \%(\mathrm{n}=822)$ in Brazil $(P<.001)($ Table 1$)$. 
Table 1. Demographics, COVID-19 experience, lifestyle, and self-reported health conditions by country among essential workers from Brazil and Spain (N=3745), April to May 2020.

\begin{tabular}{|c|c|c|c|c|}
\hline Variable & Brazil $(\mathrm{n}=2842), \mathrm{n}(\%)$ & Spain $(\mathrm{n}=903), \mathrm{n}(\%)$ & Total $(\mathrm{N}=3745), \mathrm{n}(\%)$ & $P$ value \\
\hline Screening for depression and/or anxiety & & & & $<.001$ \\
\hline Negative for both depression and anxiety & $1280(45.0)$ & $693(76.7)$ & $1973(52.7)$ & \\
\hline Positive for depression only & $262(9.2)$ & $49(5.4)$ & $311(8.3)$ & \\
\hline Positive for anxiety only & $360(12.7)$ & $74(8.2)$ & $434(11.6)$ & \\
\hline Positive for both depression and anxiety & $940(33.1)$ & $87(9.6)$ & $1027(27.4)$ & \\
\hline Sex & & & & .44 \\
\hline Male & $790(27.8)$ & $263(29.1)$ & $1053(28.1)$ & \\
\hline Female & $2052(72.2)$ & $640(70.9)$ & $2692(71.9)$ & \\
\hline Age (years), median (IQR) & $39(32-51)$ & $43(32-52)$ & $40(32-51)$ & .07 \\
\hline Educational level & & & & $<.001$ \\
\hline Primary/secondary education or professional degree & $425(15.0)$ & $242(26.8)$ & $667(17.8)$ & \\
\hline University degree & $1606(56.5)$ & $354(39.2)$ & $1960(52.3)$ & \\
\hline Master's/PhD degree & $811(28.5)$ & $307(34.0)$ & $1118(29.9)$ & \\
\hline Frontline worker & $822(28.9)$ & $457(50.6)$ & $1279(34.2)$ & $<.001$ \\
\hline People living in the household, median (IQR) ${ }^{\mathrm{a}}$ & $3(2-4)$ & $3(2-4)$ & $3(2-4)$ & .56 \\
\hline Self-isolated ${ }^{b}$ & $1501(53.3)$ & $181(20.2)$ & $1682(45.3)$ & $<.001$ \\
\hline Diagnosed with COVID- $19^{\mathrm{c}}$ & $69(2.4)$ & $35(3.9)$ & $104(2.8)$ & .02 \\
\hline Lost someone during the pandemic ${ }^{c}$ & $254(9.0)$ & $97(10.8)$ & $351(9.4)$ & .10 \\
\hline SMILE-C ${ }^{\mathrm{d}}$, median (IQR) & $78(71-84)$ & $80(75-85)$ & $79(72-85)$ & $<.001$ \\
\hline $\begin{array}{l}\text { Self-reported health (neither good nor bad, bad or very } \\
\text { bad) }\end{array}$ & $708(24.9)$ & $210(23.3)$ & $918(24.5)$ & .32 \\
\hline \multicolumn{5}{|l|}{ Diagnosed with or treated for... } \\
\hline Chronic diseases $^{\mathrm{f}}$ & $929(32.9)$ & $233(26.1)$ & $1162(31.3)$ & $<.001$ \\
\hline Mental health disorders $\mathrm{g}$ & $865(30.9)$ & $109(12.2)$ & $974(26.4)$ & $<.001$ \\
\hline Infectious diseases $^{\mathrm{h}}$ & $108(3.8)$ & $3(0.3)$ & $111(3.0)$ & $<.001$ \\
\hline Positive screening for alcohol abuse & $1260(44.3)$ & $289(32.0)$ & $1549(41.4)$ & $<.001$ \\
\hline \multicolumn{5}{|l|}{ Changes in... } \\
\hline Dietary and nutritional habits ${ }^{\mathrm{i}}$ & $1257(44.3)$ & $217(24.0)$ & $1474(39.4)$ & $<.001$ \\
\hline Substance use habits $^{\mathrm{j}}$ & $459(17.6)$ & $83(9.3)$ & $542(15.5)$ & $<.001$ \\
\hline Physical activity routine $\mathrm{k}^{\mathrm{k}}$ & $1656(58.8)$ & $584(64.7)$ & $2240(60.2)$ & .002 \\
\hline Strategies to manage stress ${ }^{1}$ & $1530(53.9)$ & $281(31.2)$ & $1811(48.5)$ & $<.001$ \\
\hline Sleep patterns ${ }^{\mathrm{i}}$ & $1219(42.9)$ & $243(26.9)$ & $1462(39.1)$ & $<.001$ \\
\hline Social support ${ }^{\mathrm{m}}$ & $1543(54.8)$ & $336(37.6)$ & $1879(50.6)$ & $<.001$ \\
\hline Time spent indoors/outdoors ${ }^{c}$ & $2461(86.7)$ & $823(91.5)$ & $3284(87.9)$ & $<.001$ \\
\hline
\end{tabular}

${ }^{a}=2$

$\mathrm{b}_{\mathrm{n}=30}$

$\mathrm{c}_{\mathrm{n}=7}$

${ }^{\mathrm{d}}$ SMILE-C: Short Multidimensional Inventory Lifestyle Evaluation-Confinement; the higher the score, the healthier the lifestyle.

$\mathrm{e}_{\mathrm{n}=5}$

${ }^{f} n=31$

http://www.jmir.org/2020/10/e22835/ 
$\mathrm{g}_{\mathrm{n}}=56$
$\mathrm{~h}_{\mathrm{n}}=6$
${ }^{{ }} \mathrm{n}=3$
$\mathrm{j}_{\mathrm{n}}=242$
$\mathrm{k}_{\mathrm{n}}=25$
${ }_{\mathrm{n}} \mathrm{n}=8$
$\mathrm{~m}_{\mathrm{n}}=33$

The prevalence of positive screenings for depression, anxiety, and comorbidity of both was $8.3 \%(n=311), 11.6 \%(n=434)$, and $27.4 \%(n=1027)$, respectively. All were higher in Brazil compared to Spain (Table 1). Table 2 describes the sociodemographic and clinical characteristics of the sample across the outcome categories (negative for depression and anxiety, positive for depression only, positive for anxiety only, and positive for both depression and anxiety). 
Table 2. Demographics, COVID-19 experience, lifestyle, and self-reported health conditions by mental health outcomes among essential workers from Brazil and Spain (N=3745), April to May 2020.

\begin{tabular}{|c|c|c|c|c|c|}
\hline Variable & $\begin{array}{l}\text { Negative for both de- } \\
\text { pression and anxiety } \\
(\mathrm{n}=1973)\end{array}$ & $\begin{array}{l}\text { Positive for depres- } \\
\text { sion only }(\mathrm{n}=311)\end{array}$ & $\begin{array}{l}\text { Positive for anxiety } \\
\text { only }(n=434)\end{array}$ & $\begin{array}{l}\text { Positive for depres- } \\
\text { sion and anxiety } \\
(n=1027)\end{array}$ & $P$ value \\
\hline Country, n (\%) & & & & & $<.001$ \\
\hline Brazil & $1280(64.9)$ & $262(84.2)$ & $360(82.9)$ & $940(91.5)$ & \\
\hline Spain & $693(35.1)$ & $49(15.8)$ & $74(17.1)$ & $87(8.5)$ & \\
\hline $\operatorname{Sex}, n(\%)$ & & & & & $<.001$ \\
\hline Male & $619(31.4)$ & $91(29.3)$ & $112(25.8)$ & $231(22.5)$ & \\
\hline Female & $1354(68.6)$ & $220(70.7)$ & $322(74.2)$ & $796(77.5)$ & \\
\hline Age (years), mean (SD) & $44.56(12.33)$ & $39.25(11.78)$ & $41.10(10.63)$ & $37.43(10.96)$ & $<.001$ \\
\hline Educational level, n (\%) & & & & & $<.001$ \\
\hline $\begin{array}{l}\text { Primary/secondary education or profes- } \\
\text { sional degree }\end{array}$ & $340(17.2)$ & $43(13.8)$ & $62(14.3)$ & $222(21.6)$ & \\
\hline University degree & $984(49.9)$ & $177(56.9)$ & $228(52.5)$ & $571(55.6)$ & \\
\hline Master's/PhD degree & $649(32.9)$ & $91(29.3)$ & $144(33.2)$ & $234(22.8)$ & \\
\hline Frontline worker, $\mathrm{n}(\%)$ & $660(33.5)$ & $83(26.7)$ & $172(39.6)$ & $364(35.4)$ & .002 \\
\hline $\begin{array}{l}\text { People living in the household, median } \\
(\mathrm{IQR})^{\mathrm{a}}\end{array}$ & $3(2-4)$ & $3(2-4)$ & $3(2-4)$ & $3(2-4)$ & .008 \\
\hline Self-isolated ${ }^{\mathrm{b}}, \mathrm{n}(\%)$ & $824(41.9)$ & $163(53.1)$ & $191(44.5)$ & $504(49.7)$ & $<.001$ \\
\hline Diagnosed with COVID-19 ${ }^{\mathrm{c}}, \mathrm{n}(\%)$ & $45(2.3)$ & $8(2.6)$ & $18(4.2)$ & $33(3.2)$ & .13 \\
\hline Lost someone in the pandemic ${ }^{\mathrm{c}}, \mathrm{n}(\%)$ & $169(8.6)$ & $24(7.7)$ & $48(11.1)$ & $110(10.7)$ & .11 \\
\hline SMILE-C $^{\mathrm{d}}$, mean (SD) & $82.23(7.71)$ & $76.16(7.73)$ & $77.67(7.43)$ & $71.41(8.73)$ & $<.001$ \\
\hline $\begin{array}{l}\text { Self-reported health (neither good nor bad, } \\
\text { bad, or very bad) }\end{array}$ & $280(14.2)$ & $77(24.8)$ & $112(25.8)$ & $449(43.8)$ & $<.001$ \\
\hline \multicolumn{6}{|l|}{ Diagnosed with or treated for... } \\
\hline Chronic diseases ${ }^{\mathrm{f}}$ & $568(29.1)$ & $75(24.2)$ & $140(32.4)$ & $379(37.3)$ & $<.001$ \\
\hline Mental health disorders ${ }^{\mathrm{g}}$ & $270(13.8)$ & $74(24.0)$ & $129(30.3)$ & $501(50.4)$ & $<.001$ \\
\hline Infectious diseases ${ }^{\mathrm{h}}$ & $50(2.5)$ & $8(2.6)$ & $14(3.2)$ & $39(3.8)$ & .26 \\
\hline Positive screening for alcohol abuse & $736(37.3)$ & $143(46.0)$ & $195(44.9)$ & $475(46.3)$ & $<.001$ \\
\hline \multicolumn{6}{|l|}{ Changes in... } \\
\hline Dietary and nutritional habits ${ }^{\mathrm{i}}$ & $641(32.5)$ & $145(46.6)$ & $207(47.7)$ & $481(46.9)$ & $<.001$ \\
\hline Substance use habits ${ }^{\mathrm{j}}$ & $213(11.4)$ & $50(17.4)$ & $64(16.2)$ & $215(22.5)$ & $<.001$ \\
\hline Physical activity routine $\mathrm{k}^{\mathrm{k}}$ & $1187(60.4)$ & $193(62.9)$ & $287(66.4)$ & $573(56.4)$ & .003 \\
\hline Strategies to manage stress ${ }^{1}$ & $905(45.9)$ & $157(50.6)$ & $255(58.9)$ & $494(48.2)$ & $<.001$ \\
\hline Sleep patterns ${ }^{\mathrm{i}}$ & $540(27.4)$ & $133(42.8)$ & $203(46.9)$ & $586(57.1)$ & $<.001$ \\
\hline Social support ${ }^{\mathrm{m}}$ & $892(45.6)$ & $158(51.6)$ & $240(55.6)$ & $589(58.0)$ & $<.001$ \\
\hline Time spent indoors/outdoors ${ }^{\mathrm{c}}$ & $1756(89.1)$ & $269(86.5)$ & $381(88.0)$ & $878(85.7)$ & .049 \\
\hline
\end{tabular}

${ }^{\mathrm{a}} \mathrm{n}=2$

$\mathrm{b}_{\mathrm{n}=30}$

${ }^{\mathrm{c}} \mathrm{n}=7$

${ }^{\mathrm{d}}$ SMILE-C: Short Multidimensional Inventory Lifestyle Evaluation-Confinement; the higher the score, the healthier the lifestyle. $e_{n=5}$ 
$\mathrm{f}_{\mathrm{n}=31}$

$\mathrm{g}_{\mathrm{n}=56}$

$\mathrm{h}_{\mathrm{n}=6}$

${ }^{i} n=3$

$\mathrm{j}_{\mathrm{n}=242}$

$\mathrm{k}_{\mathrm{n}=25}$

${ }_{\mathrm{n}}=8$

$\mathrm{m}_{\mathrm{n}=33}$

In the multinomial model, living in Brazil was associated with an AOR of 2.89 (95\% CI 2.07-4.06) for a positive screening for depression, an AOR of 2.81 (95\% CI 2.11-3.74) for anxiety, and an AOR of 5.99 (95\% CI 4.53-7.91) for both conditions compared to living in Spain. An unhealthy lifestyle was associated with an AOR of 4.00 (95\% CI 2.72-5.87) for depression, an AOR of 2.39 (95\% CI 1.80-3.20) for anxiety, and an AOR of 8.30 (95\% CI 5.90-11.7) for both conditions. Interestingly, being a frontline worker was not associated with depression only (AOR 0.81, 95\% CI 0.60-1.08), although it

increased the likelihood of having anxiety (AOR 1.49, 95\% CI 1.18-1.87) and both conditions (AOR 1.25, 95\% CI 1.02-1.53). Additionally, we found that being female, being younger, presenting moderate or substantial changes in sleep patterns during the COVID-19 pandemic, being diagnosed with or treated for mental health disorders in the last year, and reporting a reduction in self-rated health were all associated with a higher likelihood of having depression, anxiety, or both conditions (Figure 4 and Multimedia Appendix 2).

Figure 4. Factors associated with depression or anxiety or both (multinomial model) among essential workers from Brazil and Spain ( $\mathrm{n}=3745)$. April-May, 2020. Note: (1) Age was dichotomized by the sample median age. (2) The SMILE-C (Short Multidimensional Inventory Lifestyle Evaluation-Confinement was dichotomized at the percentile 75\%, the higher the score, the healthier the lifestyle).

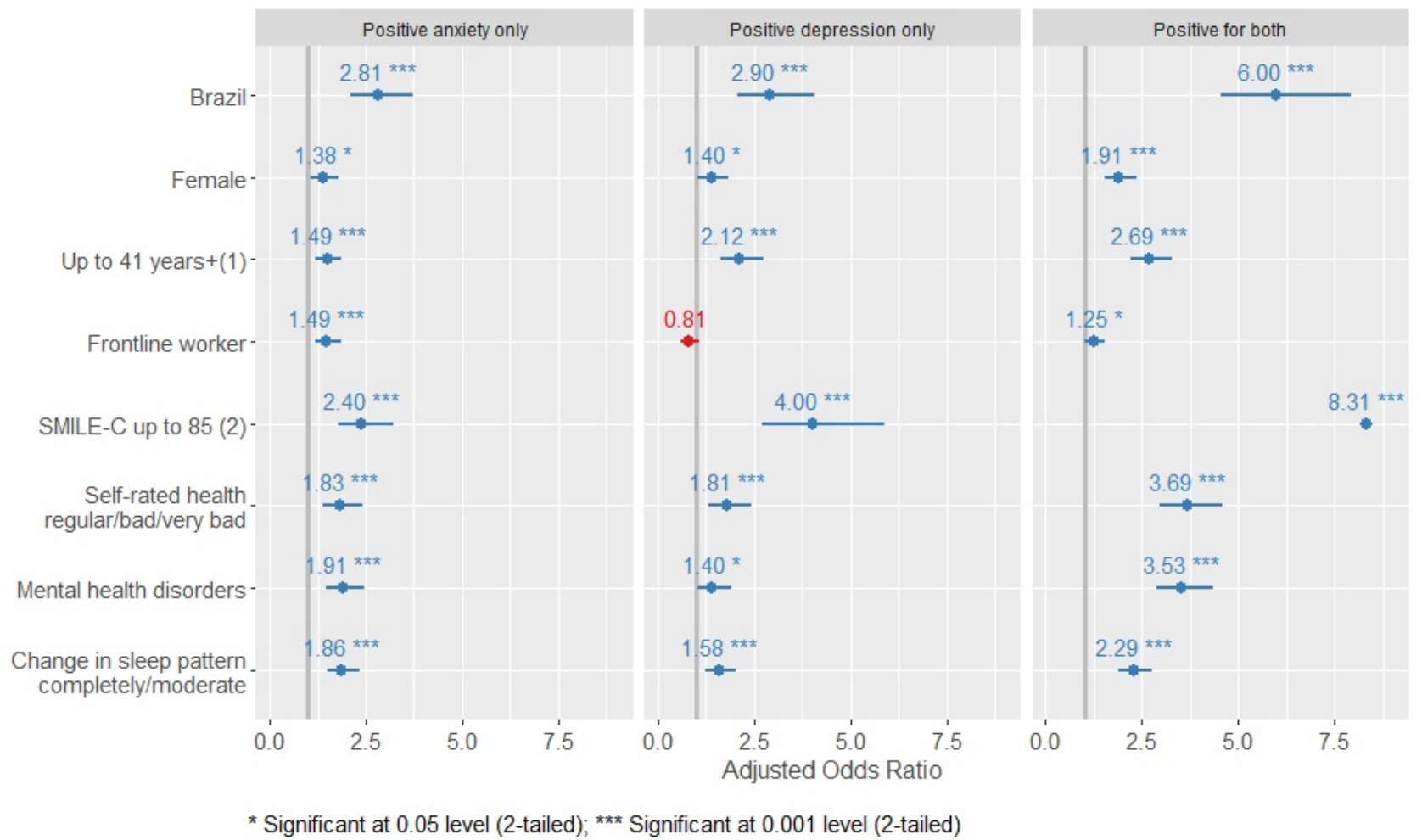

\section{Discussion}

In a web survey of 3745 essential workers from Brazil and Spain, we showed $8.3 \%, 11.6 \%$, and $27.4 \%$ presenting positive screenings for depression, anxiety, and both conditions, respectively. As in previous studies conducted during the COVID-19 pandemic, we found that women, younger workers, frontline workers, those reporting a mental health diagnosis or treatment in the last 12 months, and those reporting changes in sleep patterns presented a higher likelihood of a positive screening for anxiety and/or depression. Most importantly, higher odds ratios were observed in those living in Brazil and in those following an unhealthy lifestyle.

During data collection, Spain had 4 times the number of COVID-19 deaths than Brazil and had adopted a strict lockdown policy. It could be expected that essential workers under these conditions would be more prone to present anxiety and depressive symptoms. However, Brazil has additional social, structural, and political problems that may affect mental health. Recently, Baqui et al [65] reported on the higher mortality risk 
among "pardo" and Black Brazilians admitted to hospital due to COVID-19; ethnicity was the second most important risk factor for death (after age). In addition, the authors highlighted that comorbid diseases and death were more common among Brazilians from the North region compared to the Central-South (except for Rio de Janeiro). Ribeiro et al [66] highlighted that the worst public health and socioeconomic scenarios were present in the northern regions of Brazil; higher proportions of individuals living in substandard housing (slums), with reduced schooling and a lack of sanitation and piped water, may interfere with adherence to hygiene recommendations. Although both papers discussed intracountry inequalities, social and health inequalities may be even higher between different countries [67] (Figure 1). In addition, the political instability and the government's failure to acknowledge the seriousness of the pandemic (eg, official data on COVID-19 was not being published) [68] may be worsening the consequences of COVID-19 in Brazil, including repercussions concerning the mental health of essential workers. These workers may be seeing a high number of casualties, and working under intense fear and feelings of impotence, which may be related to the higher odds for anxiety and depression observed in our study.

Self-reported unhealthy lifestyle behaviors during confinement were associated with an increased likelihood of presenting a positive screening for both anxiety and depression in our study. Several studies have assessed psychological distress in HCWs during COVID-19, but its association with lifestyle remains underresearched. To our knowledge, the present study is the first web survey designed to assess a wide range of lifestyle changes and its relationship with anxiety and depression among essential workers during the pandemic. Among HCWs from New York, where almost half screened positive for depression, and one third for anxiety [30], physical activity/exercise was the most commonly endorsed solution to cope with COVID-19-related psychological distress, but its relationship with anxiety and depression was not explored. Our results are consistent with those pertaining to the general population and clinical studies. For instance, in Australia, adults who reported negative changes in physical activity, sleep, smoking, and alcohol intake after the onset of COVID-19 were more likely to have higher rates of depression, anxiety, and stress symptoms [69]. In the same way, individuals with anxiety and depression have shown higher ratios of unhealthy lifestyle habits, including poor diet quality, impaired sleep, reduced physical activity, smoking, and substance and/or alcohol misuse [39]. Based on the present results, the relationship between anxiety/depression and lifestyle as a multidimensional construct applies also to essential workers during the COVID-19 pandemic.

Our findings regarding sleep changes are also in accordance with a meta-analysis that showed that about $50 \%$ of HCWs have poor sleep quality in general (ie, during nonpandemic times) [36]. Subjective sleep quality, defined by the satisfaction with one's overall sleep experience, may worsen among frontline HCWs treating patients with COVID-19 [42]. The present study expands the association between changes in sleep and anxiety/depression to a wider group of essential workers. This concurs with evidence supporting a bidirectional relationship between sleep disturbances and anxiety/depression [70].
Moreover, a reduced quality of sleep was associated with higher levels of depressive and anxiety symptoms during the COVID-19 lockdown in Italy [71].

Our results are in accordance with most of the literature: women and youth [17,31,32,72], frontline workers [31,33,34], a diagnosis of or treatment for mental health disorders in the past 12 months, and self-rated poor health [17] all increased the likelihood of depression and anxiety. Mental health disorders are associated with higher mortality rates and shorter life expectancies [73]. Our results, which support that of The Lancet Commission on Global Mental Health and Sustainable Development [74], showed the importance of social and environmental factors in mental health and highlighted the additional challenges experienced by populations living in countries with higher rates of inequality.

Consistent with other web surveys, where the population is recruited through social networks, our sample is not probabilistic and may therefore not represent the entire population of essential workers from Brazil and Spain [75]. Additionally, in 2018, 67\% of Brazilian households had internet access (48\% among the lower economic strata) [76] compared to $86.4 \%$ in Spain [77]. Although this difference may not have contributed to the different prevalence found between the countries (as we may have surveyed individuals with age, income, and schooling more similar to the Spanish population), we may be overrepresenting the highest socioeconomic strata in Brazil. Women were also overrepresented in both countries, as in many other web surveys conducted during the COVID-19 pandemic $[18,23,32,34,72]$. Due to the length of the original questionnaire, we did not include questions regarding gender and ethnicity/race, which may be associated with higher vulnerability to COVID-19 [65] and mental health outcomes. Additionally, we did not ask about the specific profession of essential workers and were not able to assess which professional groups were more vulnerable to mental health problems. In the United States [78], over 75\% of Americans were estimated to work in occupations (including health care, manufacturing, retail, and food services) that are challenging to do from home. It was suggested that those workers may receive low wages and be subjected to stress due to the lower income and job insecurity, which could result in a large burden of mental health disorders.

One important strength of our survey was to disseminate reliable information on COVID-19 and strategies to maintain a healthy lifestyle. Considering the massive amount of information available, including fake news, and all the technology available for creating and disseminating online surveys, we believe that researchers can contribute to society by providing valuable information to respondents while obtaining data. Studies addressing participants' opinions and effectiveness, when appropriate, on this information should be considered in the future.

Finally, our results provide additional support for The Lancet COVID-19 Commission [79], and are in accordance with Vigo et al [80], showing that countries with higher rates of inequality may be facing an important mental health burden in the forthcoming months. 


\section{Acknowledgments}

We would like to thank Gabriel Madeira and Ronaldo I Moreira for their assistance in creating and testing the online questionnaire; Thais Martini for social media management; Juliana Krapp and Daniele Souza for communications advice; all the institutions and individuals who promoted the survey; and all the individuals who answered it. RBDB is grateful for long-term funding from the Fundação de Amparo à Pesquisa do Estado do Rio de Janeiro (FAPERJ) (E-26/203.154/2017) and the Conselho Nacional de Desenvolvimento Científico e Tecnológico (CNPq) (310541/2017-4). FIB acknowledges funding from FAPERJ (Health Networks; E-26/010.002428/2019). FK acknowledges funding from the Fundação de Amparo à Pesquisa do Estado de São Paulo (INCT 2014, 2014/50891-1), CNPq (INCT 465458/2014-9), and the Fundação de Amparo à Pesquisa do Estado do Rio Grande do Sul (47177.584.16785.16042020).

Funding sources had no role in the study design, data collection, analysis, interpretation of data, writing of the report, or in the decision to submit the paper for publication.

\section{Authors' Contributions}

RBDB, VBM, and FK conceived and designed the study. JCM, TDAC, and PB analyzed the data and created the figures. RBDB and FIB supervised data analysis. RBDB, VBM, and BC revised the literature. RBDB wrote the first draft, and all authors revised and provided significant intellectual contribution. All the authors approved the submitted version.

\section{Conflicts of Interest}

VBM has been a consultant, advisor, or Continuing Medical Education speaker over the last 3 years for the following companies: Angelini, Ferrer, Lundbeck, Nutrición Médica, and Otsuka. The remaining authors have no conflicts to declare.

\section{Multimedia Appendix 1}

Data collection.

[PDF File (Adobe PDF File), 428 KB-Multimedia Appendix 1]

\section{Multimedia Appendix 2}

Statistical analyses.

[DOCX File, 224 KB-Multimedia Appendix 2]

\section{References}

1. Silveira M, Barros A, Horta B, Pellanda L, Victora G, Dellagostin O, et al. Population-based surveys of antibodies against SARS-CoV-2 in Southern Brazil. medRxiv Preprint posted online on May 10, 2020. [doi: 10.1101/2020.05.01.20087205]

2. Amsalem D, Dixon LB, Neria Y. The Coronavirus Disease 2019 (COVID-19) Outbreak and Mental Health: Current Risks and Recommended Actions. JAMA Psychiatry 2020 Jun 24. [doi: 10.1001/jamapsychiatry.2020.1730] [Medline: $\underline{32579160]}$

3. Greenberg N, Brooks SK, Wessely S, Tracy DK. How might the NHS protect the mental health of health-care workers after the COVID-19 crisis? Lancet Psychiatry 2020 May 28 [FREE Full text] [doi: 10.1016/S2215-0366(20)30224-8] [Medline: $\underline{32473664]}$

4. Balanzá-Martínez V, Atienza-Carbonell B, Kapczinski F, De Boni RB. Lifestyle behaviours during the COVID-19 - time to connect. Acta Psychiatr Scand 2020 May;141(5):399-400 [FREE Full text] [doi: 10.1111/acps.13177] [Medline: 32324252]

5. Verma S, Mishra A. Depression, anxiety, and stress and socio-demographic correlates among general Indian public during COVID-19. Int J Soc Psychiatry 2020 Dec 20;66(8):756-762. [doi: 10.1177/0020764020934508] [Medline: 32567466]

6. Hou T, Zhang T, Cai W, Song X, Chen A, Deng G, et al. Social support and mental health among health care workers during Coronavirus Disease 2019 outbreak: A moderated mediation model. PLoS One 2020;15(5):e0233831 [FREE Full text] [doi: 10.1371/journal.pone.0233831] [Medline: 32470007]

7. Moghanibashi-Mansourieh A. Assessing the anxiety level of Iranian general population during COVID-19 outbreak. Asian J Psychiatr 2020 Jun;51:102076 [FREE Full text] [doi: 10.1016/j.ajp.2020.102076] [Medline: 32334409]

8. Tian F, Li H, Tian S, Yang J, Shao J, Tian C. Psychological symptoms of ordinary Chinese citizens based on SCL-90 during the level I emergency response to COVID-19. Psychiatry Res 2020 Jun;288:112992 [FREE Full text] [doi: 10.1016/j.psychres.2020.112992] [Medline: 32302816]

9. Huang Y, Zhao N. Generalized anxiety disorder, depressive symptoms and sleep quality during COVID-19 outbreak in China: a web-based cross-sectional survey. Psychiatry Res 2020 Jun;288:112954 [FREE Full text] [doi: 10.1016/j.psychres.2020.112954] [Medline: 32325383]

10. Ni MY, Yang L, Leung CMC, Li N, Yao XI, Wang Y, et al. Mental Health, Risk Factors, and Social Media Use During the COVID-19 Epidemic and Cordon Sanitaire Among the Community and Health Professionals in Wuhan, China: 
Cross-Sectional Survey. JMIR Ment Health 2020 May 12;7(5):e19009 [FREE Full text] [doi: 10.2196/19009] [Medline: 32365044]

11. Lu W, Wang H, Lin Y, Li L. Psychological status of medical workforce during the COVID-19 pandemic: A cross-sectional study. Psychiatry Res 2020 Jun;288:112936 [FREE Full text] [doi: 10.1016/j.psychres.2020.112936] [Medline: 32276196]

12. García-Fernández L, Romero-Ferreiro V, López-Roldán PD, Padilla S, Calero-Sierra I, Monzó-García M, et al. Mental health impact of COVID-19 pandemic on Spanish healthcare workers. Psychol Med 2020 May 27:1-3 [FREE Full text] [doi: 10.1017/S0033291720002019] [Medline: 32456735]

13. Mo Y, Deng L, Zhang L, Lang Q, Liao C, Wang N, et al. Work stress among Chinese nurses to support Wuhan in fighting against COVID-19 epidemic. J Nurs Manag 2020 Jul;28(5):1002-1009 [FREE Full text] [doi: 10.1111/jonm.13014] [Medline: 32255222]

14. Tabah A, Ramanan M, Laupland KB, Buetti N, Cortegiani A, Mellinghoff J, PPE-SAFE contributors. Personal protective equipment and intensive care unit healthcare worker safety in the COVID-19 era (PPE-SAFE): An international survey. $\mathrm{J}$ Crit Care 2020 Oct;59:70-75 [FREE Full text] [doi: 10.1016/j.jcrc.2020.06.005] [Medline: 32570052]

15. El-Hage W, Hingray C, Lemogne C, Yrondi A, Brunault P, Bienvenu T, et al. [Health professionals facing the coronavirus disease 2019 (COVID-19) pandemic: What are the mental health risks?]. Encephale 2020 Jun;46(3S):S73-S80 [FREE Full text] [doi: 10.1016/j.encep.2020.04.008] [Medline: 32370984]

16. Morgantini LA, Naha U, Wang H, Francavilla S, Acar O, Flores JM, et al. Factors Contributing to Healthcare Professional Burnout During the COVID-19 Pandemic: A Rapid Turnaround Global Survey. medRxiv 2020 May 22 [FREE Full text] [doi: 10.1101/2020.05.17.20101915] [Medline: 32511501]

17. Barello S, Palamenghi L, Graffigna G. Burnout and somatic symptoms among frontline healthcare professionals at the peak of the Italian COVID-19 pandemic. Psychiatry Res 2020 May 27;290:113129 [FREE Full text] [doi:

10.1016/j.psychres.2020.113129] [Medline: 32485487]

18. Temsah M, Al-Sohime F, Alamro N, Al-Eyadhy A, Al-Hasan K, Jamal A, et al. The psychological impact of COVID-19 pandemic on health care workers in a MERS-CoV endemic country. J Infect Public Health 2020 Jun;13(6):877-882 [FREE Full text] [doi: 10.1016/j.jiph.2020.05.021] [Medline: 32505461]

19. Du J, Dong L, Wang T, Yuan C, Fu R, Zhang L, et al. Psychological symptoms among frontline healthcare workers during COVID-19 outbreak in Wuhan. Gen Hosp Psychiatry 2020 Apr 03 [FREE Full text] [doi:

10.1016/j.genhosppsych.2020.03.011] [Medline: 32381270]

20. Vindegaard N, Benros ME. COVID-19 pandemic and mental health consequences: Systematic review of the current evidence. Brain Behav Immun 2020 Oct 30;89:531-542 [FREE Full text] [doi: 10.1016/j.bbi.2020.05.048] [Medline: 32485289]

21. Spoorthy MS, Pratapa SK, Mahant S. Mental health problems faced by healthcare workers due to the COVID-19 pandemic-A review. Asian J Psychiatr 2020 Jun;51:102119 [FREE Full text] [doi: 10.1016/j.ajp.2020.102119] [Medline: 32339895]

22. Pappa S, Ntella V, Giannakas T, Giannakoulis VG, Papoutsi E, Katsaounou P. Prevalence of depression, anxiety, and insomnia among healthcare workers during the COVID-19 pandemic: A systematic review and meta-analysis. Brain Behav Immun 2020 Aug;88:901-907 [FREE Full text] [doi: 10.1016/j.bbi.2020.05.026] [Medline: 32437915]

23. Chew NW, Lee GK, Tan BY, Jing M, Goh Y, Ngiam NJ, et al. A multinational, multicentre study on the psychological outcomes and associated physical symptoms amongst healthcare workers during COVID-19 outbreak. Brain Behav Immun 2020 Aug;88:559-565 [FREE Full text] [doi: 10.1016/j.bbi.2020.04.049] [Medline: 32330593]

24. Sharif S, Amin F, Hafiz M, Benzel E, Peev N, Dahlan RH, World Spinal Column Society Executive Board. COVID 19-Depression and Neurosurgeons. World Neurosurg 2020 Jun 06 [FREE Full text] [doi: 10.1016/j.wneu.2020.06.007] [Medline: 32512242]

25. Vanni G, Materazzo M, Santori F, Pellicciaro M, Costesta M, Orsaria P, et al. The Effect of Coronavirus (COVID-19) on Breast Cancer Teamwork: A Multicentric Survey. In Vivo 2020 Jun;34(3 Suppl):1685-1694. [doi: 10.21873/invivo.11962] [Medline: $\underline{\text { 32503830] }}$

26. Wang S, Xie L, Xu Y, Yu S, Yao B, Xiang D. Sleep disturbances among medical workers during the outbreak of COVID-2019. Occup Med (Lond) 2020 Jul 17;70(5):364-369 [FREE Full text] [doi: 10.1093/occmed/kqaa074] [Medline: $\underline{32372077]}$

27. Zhang SX, Liu J, Afshar Jahanshahi A, Nawaser K, Yousefi A, Li J, et al. At the height of the storm: Healthcare staff's health conditions and job satisfaction and their associated predictors during the epidemic peak of COVID-19. Brain Behav Immun 2020 Jul;87:144-146 [FREE Full text] [doi: 10.1016/j.bbi.2020.05.010] [Medline: 32387345]

28. Tan BYQ, Chew NWS, Lee GKH, Jing M, Goh Y, Yeo LLL, et al. Psychological Impact of the COVID-19 Pandemic on Health Care Workers in Singapore. Ann Intern Med 2020 Aug 18;173(4):317-320. [doi: 10.7326/M20-1083] [Medline: $\underline{32251513]}$

29. Yang S, Kwak SG, Ko EJ, Chang MC. The Mental Health Burden of the COVID-19 Pandemic on Physical Therapists. Int J Environ Res Public Health 2020 May 25;17(10) [FREE Full text] [doi: 10.3390/ijerph17103723] [Medline: 32466164]

30. Shechter A, Diaz F, Moise N, Anstey DE, Ye S, Agarwal S, et al. Psychological distress, coping behaviors, and preferences for support among New York healthcare workers during the COVID-19 pandemic. Gen Hosp Psychiatry 2020 Sep;66:1-8 [FREE Full text] [doi: 10.1016/j.genhosppsych.2020.06.007] [Medline: 32590254] 
31. Elbay RY, Kurtulmuş A, Arpacioğlu S, Karadere E. Depression, anxiety, stress levels of physicians and associated factors in Covid-19 pandemics. Psychiatry Res 2020 Aug;290:113130 [FREE Full text] [doi: 10.1016/j.psychres.2020.113130] [Medline: $\underline{\text { 32497969] }}$

32. Rossi R, Socci V, Pacitti F, Di Lorenzo G, Di Marco A, Siracusano A, et al. Mental Health Outcomes Among Frontline and Second-Line Health Care Workers During the Coronavirus Disease 2019 (COVID-19) Pandemic in Italy. JAMA Netw Open 2020 May 01;3(5):e2010185 [FREE Full text] [doi: 10.1001/jamanetworkopen.2020.10185] [Medline: 32463467]

33. Liu C, Yang Y, Zhang X, Xu X, Dou Q, Zhang W, et al. The prevalence and influencing factors in anxiety in medical workers fighting COVID-19 in China: a cross-sectional survey. Epidemiol Infect 2020 May 20;148:e98 [FREE Full text] [doi: 10.1017/S0950268820001107] [Medline: 32430088]

34. Lai J, Ma S, Wang Y, Cai Z, Hu J, Wei N, et al. Factors Associated With Mental Health Outcomes Among Health Care Workers Exposed to Coronavirus Disease 2019. JAMA Netw Open 2020 Mar 02;3(3):e203976 [FREE Full text] [doi: 10.1001/jamanetworkopen.2020.3976] [Medline: $\underline{\text { 32202646] }}$

35. Li G, Miao J, Wang H, Xu S, Sun W, Fan Y, et al. Psychological impact on women health workers involved in COVID-19 outbreak in Wuhan: a cross-sectional study. J Neurol Neurosurg Psychiatry 2020 Aug;91(8):895-897. [doi: 10.1136/jnnp-2020-323134] [Medline: 32366684]

36. Qiu D, Yu Y, Li R, Li Y, Xiao S. Prevalence of sleep disturbances in Chinese healthcare professionals: a systematic review and meta-analysis. Sleep Med 2020 Mar;67:258-266. [doi: 10.1016/j.sleep.2019.01.047] [Medline: $\underline{31040078]}$

37. Noordsy DL. Lifestyle Psychiatry. Washington DC: American Psychiatric Association; 2019.

38. Firth J, Ward PB, Stubbs B. Editorial: Lifestyle Psychiatry. Front Psychiatry 2019 Aug 26;10:597 [FREE Full text] [doi: 10.3389/fpsyt.2019.00597] [Medline: $\underline{31507466]}$

39. Firth J, Rosenbaum S, Galletly C, Siddiqi N, Stubbs B, Killackey E, et al. Protecting physical health in people with mental illness - Authors' reply. The Lancet Psychiatry 2019 Nov;6(11):890-891. [doi: 10.1016/s2215-0366(19)30387-6]

40. Firth J, Solmi M, Wootton RE, Vancampfort D, Schuch FB, Hoare E, et al. A meta-review of "lifestyle psychiatry": the role of exercise, smoking, diet and sleep in the prevention and treatment of mental disorders. World Psychiatry 2020 Oct 15;19(3):360-380 [FREE Full text] [doi: 10.1002/wps.20773] [Medline: 32931092]

41. Balanzá-Martínez V, Kapczinski F, de Azevedo Cardoso T, Atienza-Carbonell B, Rosa AR, Mota JC, et al. The assessment of lifestyle changes during the COVID-19 pandemic using a multidimensional scale. Rev Psiquiatr Salud Ment 2020 Aug 29 [FREE Full text] [doi: 10.1016/j.rpsm.2020.07.003] [Medline: 32962948]

42. Xiao H, Zhang Y, Kong D, Li S, Yang N. The Effects of Social Support on Sleep Quality of Medical Staff Treating Patients with Coronavirus Disease 2019 (COVID-19) in January and February 2020 in China. Med Sci Monit 2020 Mar 05;26:e923549 [FREE Full text] [doi: 10.12659/MSM.923549] [Medline: 32132521]

43. Kastorini C, Milionis HJ, Esposito K, Giugliano D, Goudevenos JA, Panagiotakos DB. The effect of Mediterranean diet on metabolic syndrome and its components: a meta-analysis of 50 studies and 534,906 individuals. J Am Coll Cardiol 2011 Mar 15;57(11):1299-1313 [FREE Full text] [doi: 10.1016/j.jacc.2010.09.073] [Medline: 21392646]

44. Gleeson M, Bishop NC, Stensel DJ, Lindley MR, Mastana SS, Nimmo MA. The anti-inflammatory effects of exercise: mechanisms and implications for the prevention and treatment of disease. Nat Rev Immunol 2011 Aug 05;11(9):607-615. [doi: 10.1038/nri3041] [Medline: 21818123]

45. Donkin A, Goldblatt P, Allen J, Nathanson V, Marmot M. Global action on the social determinants of health. BMJ Glob Health 2018 Dec 01;3(Suppl 1):e000603. [doi: 10.1136/bmjgh-2017-000603] [Medline: 29379648]

46. Holmes SM, Hansen H, Jenks A, Stonington SD, Morse M, Greene JA, et al. Misdiagnosis, Mistreatment, and Harm When Medical Care Ignores Social Forces. N Engl J Med 2020 Mar 19;382(12):1083-1086. [doi: 10.1056/NEJMp1916269] [Medline: $\underline{\text { 32187466] }}$

47. Country profiles-Brazil, Spain. Seattle, WA: IHME, University of Washington. 2018. URL: http://www.healthdata.org/ results/country-profiles [accessed 2020-07-03]

48. Coronavirus Disease (COVID-19) Dashboard - Brazil. World Health Organization. 2020. URL: https://covid19.who.int/ region/amro/country/br [accessed 2020-07-03]

49. Coronavirus Disease (COVID-19) Dashboard - Spain. World Health Organization. 2020. URL: https://covid19.who.int/ region/euro/country/es [accessed 2020-07-03]

50. World Development Indicators. World Bank. URL: http://datatopics.worldbank.org/world-development-indicators/themes/ poverty-and-inequality.html [accessed 2020-07-03]

51. Tiffany J. Respondent-driven sampling in participatory research contexts: participant-driven recruitment. J Urban Health 2006 Nov;83(6 Suppl):i113-i124 [FREE Full text] [doi: 10.1007/s11524-006-9107-9] [Medline: 16933100]

52. Kroenke K, Spitzer RL, Williams JBW. The Patient Health Questionnaire-2: validity of a two-item depression screener. Med Care 2003 Nov;41(11):1284-1292. [doi: 10.1097/01.MLR.0000093487.78664.3C] [Medline: 14583691]

53. de Lima Osório F, Vilela Mendes A, Crippa JA, Loureiro SR. Study of the discriminative validity of the PHQ-9 and PHQ-2 in a sample of Brazilian women in the context of primary health care. Perspect Psychiatr Care 2009 Jul;45(3):216-227. [doi: 10.1111/j.1744-6163.2009.00224.x] [Medline: 19566694] 
54. Rodríguez-Muñoz MDLF, Castelao Legazpi PC, Olivares Crespo ME, Soto Balbuena C, Izquierdo Méndez N, Ferrer Barrientos FJ, et al. [PHQ-2 as First Screening Instrument of Prenatal Depression in Primary Health Care, Spain]. Rev Esp Salud Publica 2017 Jan 30;91 [FREE Full text] [Medline: 28134236]

55. Cano-Vindel A, Muñoz-Navarro R, Medrano LA, Ruiz-Rodríguez P, González-Blanch C, Gómez-Castillo MD, PsicAP Research Group. A computerized version of the Patient Health Questionnaire-4 as an ultra-brief screening tool to detect emotional disorders in primary care. J Affect Disord 2018 Jul;234:247-255. [doi: 10.1016/j.jad.2018.01.030] [Medline: 29549826]

56. Spitzer RL, Kroenke K, Williams JBW, Löwe B. A brief measure for assessing generalized anxiety disorder: the GAD-7. Arch Intern Med 2006 May 22;166(10):1092-1097. [doi: 10.1001/archinte.166.10.1092] [Medline: 16717171]

57. Jylhä M. What is self-rated health and why does it predict mortality? Towards a unified conceptual model. Soc Sci Med 2009 Aug;69(3):307-316. [doi: 10.1016/j.socscimed.2009.05.013] [Medline: 19520474]

58. Instituto Brasileiro de Geografia e Estatística. Pesquisa Nacional de Saúde 2013: percepção do estado de saúde, estilos de vida e doenças crônicass: Brasil, Grandes Regiões e Unidades da Federação. Rio de Janeiro: IBGE; 2014.

59. Bush K, Kivlahan DR, McDonell MB, Fihn SD, Bradley KA. The AUDIT alcohol consumption questions (AUDIT-C): an effective brief screening test for problem drinking. Ambulatory Care Quality Improvement Project (ACQUIP). Alcohol Use Disorders Identification Test. Arch Intern Med 1998 Sep 14;158(16):1789-1795. [doi: 10.1001/archinte.158.16.1789] [Medline: $\underline{\text { 9738608] }}$

60. Zou H, Hastie T. Regularization and variable selection via the elastic net. J Royal Statistical Soc B 2005 Apr;67(2):301-320. [doi: $10.1111 /$ j.1467-9868.2005.00503.x]

61. Musoro JZ, Zwinderman AH, Puhan MA, ter Riet G, Geskus RB. Validation of prediction models based on lasso regression with multiply imputed data. BMC Med Res Methodol 2014 Oct 16;14:116 [FREE Full text] [doi: 10.1186/1471-2288-14-116] [Medline: 25323009]

62. Tutz G, Pößnecker W, Uhlmann L. Variable selection in general multinomial logit models. 2015 Feb;82:207-222. [doi: 10.1016/j.csda.2014.09.009]

63. de Jong VMT, Eijkemans MJC, van Calster B, Timmerman D, Moons KGM, Steyerberg EW, et al. Sample size considerations and predictive performance of multinomial logistic prediction models. Stat Med 2019 Apr 30;38(9):1601-1619 [FREE Full text] [doi: 10.1002/sim.8063] [Medline: 30614028 ]

64. Smith GCS, Seaman SR, Wood AM, Royston P, White IR. Correcting for optimistic prediction in small data sets. Am J Epidemiol 2014 Aug 01;180(3):318-324 [FREE Full text] [doi: 10.1093/aje/kwu140] [Medline: 24966219]

65. Baqui P, Bica I, Marra V, Ercole A, van DSM. Ethnic and regional variations in hospital mortality from COVID-19 in Brazil: a cross-sectional observational study. medRxiv Preprint posted online on May 10, 2020. [doi: $10.1101 / 2020.05 .19 .20107094]$

66. Ribeiro H, Lima VM, Waldman EA. In the COVID-19 pandemic in Brazil, do brown lives matter? Lancet Glob Health 2020 Aug;8(8):e976-e977 [FREE Full text] [doi: 10.1016/S2214-109X(20)30314-4] [Medline: 32622403]

67. Nepomuceno MR, Acosta E, Alburez-Gutierrez D, Aburto JM, Gagnon A, Turra CM. Besides population age structure, health and other demographic factors can contribute to understanding the COVID-19 burden. Proc Natl Acad Sci U S A 2020 Jun 23;117(25):13881-13883. [doi: 10.1073/pnas.2008760117] [Medline: 32576710]

68. The Lancet Infectious Diseases. Political casualties of the COVID-19 pandemic. Lancet Infect Dis 2020 Jul;20(7):755 [FREE Full text] [doi: 10.1016/S1473-3099(20)30496-5] [Medline: 32534606]

69. Stanton R, To QG, Khalesi S, Williams SL, Alley SJ, Thwaite TL, et al. Depression, Anxiety and Stress during COVID-19: Associations with Changes in Physical Activity, Sleep, Tobacco and Alcohol Use in Australian Adults. Int J Environ Res Public Health 2020 Jun 07;17(11):4065 [FREE Full text] [doi: 10.3390/ijerph17114065] [Medline: $\underline{32517294]}$

70. Alvaro PK, Roberts RM, Harris JK. A Systematic Review Assessing Bidirectionality between Sleep Disturbances, Anxiety, and Depression. Sleep 2013 Jul 01;36(7):1059-1068 [FREE Full text] [doi: 10.5665/sleep.2810] [Medline: 23814343]

71. Cellini N, Canale N, Mioni G, Costa S. Changes in sleep pattern, sense of time, and digital media use during COVID-19 lockdown in Italy. PsyArXiv Preprint posted online on May 15, 2020. [doi: 10.31234/osf.io/284mr]

72. Kang L, Ma S, Chen M, Yang J, Wang Y, Li R, et al. Impact on mental health and perceptions of psychological care among medical and nursing staff in Wuhan during the 2019 novel coronavirus disease outbreak: A cross-sectional study. Brain Behav Immun 2020 Jul;87:11-17 [FREE Full text] [doi: 10.1016/j.bbi.2020.03.028] [Medline: 32240764]

73. Plana-Ripoll O, Pedersen CB, Agerbo E, Holtz Y, Erlangsen A, Canudas-Romo V, et al. A comprehensive analysis of mortality-related health metrics associated with mental disorders: a nationwide, register-based cohort study. The Lancet 2019 Nov;394(10211):1827-1835. [doi: 10.1016/s0140-6736(19)32316-5]

74. Patel V, Saxena S, Lund C, Thornicroft G, Baingana F, Bolton P, et al. The Lancet Commission on global mental health and sustainable development. The Lancet 2018 Oct;392(10157):1553-1598. [doi: 10.1016/S0140-6736(18)31612-X]

75. De Boni RB. Web surveys in the time of COVID-19. Cad Saude Publica 2020;36(7):e00155820. [doi: 10.1590/0102-311x00155820] [Medline: 32638874]

76. TIC Domicílios - 2019. Núcleo de Informação e Coordenação do Ponto BR. 2020. URL: https://cetic.br/pesquisa/domicilios/ indicadores/ [accessed 2020-05-28] 
77. Encuesta sobre equipamiento y uso de tecnologías de información y comunicación en los hogares. INE. 2019. URL: https:/ /www.ine.es/prensa/tich 2019.pdf [accessed 2020-05-28]

78. Baker MG. Nonrelocatable Occupations at Increased Risk During Pandemics: United States, 2018. Am J Public Health 2020 Aug;110(8):1126-1132. [doi: 10.2105/ajph.2020.305738]

79. Sachs JD, Horton R, Bagenal J, Ben Amor Y, Karadag Caman O, Lafortune G. The Lancet COVID-19 Commission. The Lancet 2020 Aug;396(10249):454-455. [doi: 10.1016/s0140-6736(20)31494-x]

80. Vigo D, Thornicroft G, Gureje O. The Differential Outcomes of Coronavirus Disease 2019 in Low- and Middle-Income Countries vs High-Income Countries. JAMA Psychiatry 2020 Jun 11. [doi: 10.1001/jamapsychiatry.2020.2174] [Medline: $\underline{32525529}$ ]

\author{
Abbreviations \\ AOR: adjusted odds ratio \\ AUDIT-C: Alcohol Use Disorder Identification Test \\ CNPq: Conselho Nacional de Desenvolvimento Científico e Tecnológico \\ CONEP: Comissão Nacional de Ética em Pesquisa \\ FAPERJ: Fundação de Amparo à Pesquisa do Estado do Rio de Janeiro \\ GAD-7: Generalized Anxiety Disorder 7-item \\ GDP: gross domestic product \\ HCW: health care worker \\ IP: Internet Protocol \\ LASSO: Least Absolute Shrinkage and Selection Operator \\ PHQ-2: Patient Health Questionnaire-2 \\ SMILE-C: Short Multidimensional Inventory Lifestyle Evaluation-Confinement
}

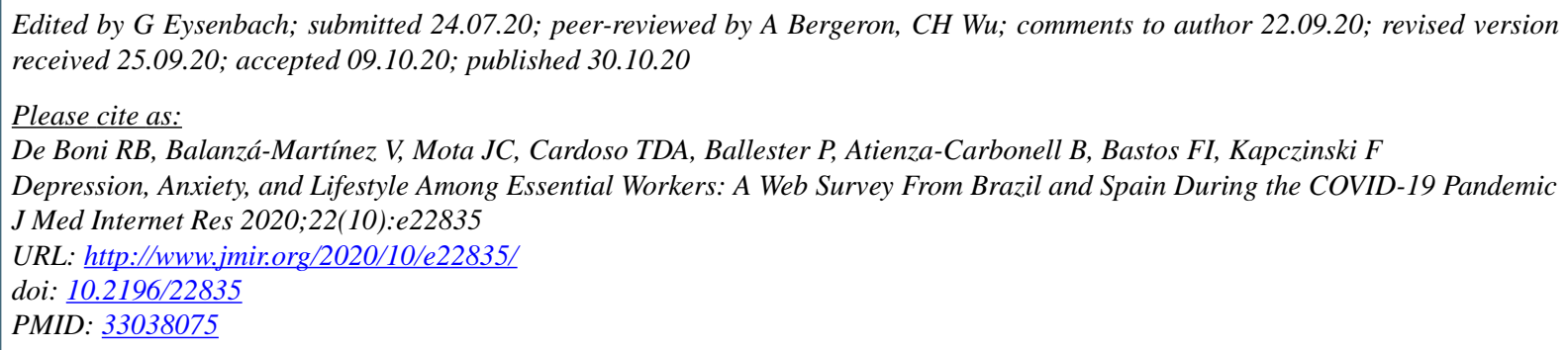

CRaquel Brandini De Boni, Vicent Balanzá-Martínez, Jurema Correa Mota, Taiane De Azevedo Cardoso, Pedro Ballester, Beatriz Atienza-Carbonell, Francisco I Bastos, Flavio Kapczinski. Originally published in the Journal of Medical Internet Research (http://www.jmir.org), 30.10.2020. This is an open-access article distributed under the terms of the Creative Commons Attribution License (https://creativecommons.org/licenses/by/4.0/), which permits unrestricted use, distribution, and reproduction in any medium, provided the original work, first published in the Journal of Medical Internet Research, is properly cited. The complete bibliographic information, a link to the original publication on http://www.jmir.org/, as well as this copyright and license information must be included. 